\title{
Temporal Dynamics of Corn Flea Beetle Populations Infested with Pantoea stewartii, Causal Agent of Stewart's Disease of Corn
}

\author{
P. D. Esker and F. W. Nutter, Jr.
}

Department of Plant Pathology, Iowa State University, Ames 50011.

Accepted for publication 10 October 2002.

\section{ABSTRACT}

Esker, P. D., and Nutter, F. W., Jr. 2003. Temporal dynamics of corn flea beetle populations infested with Pantoea stewartii, causal agent of Stewart's disease of corn. Phytopathology 93:210-218.

In order to better understand the epidemiology of the Stewart's disease of corn pathosystem, quantitative information concerning the temporal dynamics of the amount of pathogen inoculum present in the form of Pantoea stewartii-infested corn flea beetles (Chaetocnema pulicaria) is needed. Temporal changes in the proportion of $P$. stewartii-infested corn flea beetle populations were monitored by testing individual corn flea beetles for the presence of $P$. stewartii using a peroxidase-labeled, enzyme-linked immunosorbent assay. Approximately 90 corn flea beetles were collected each week from seven locations in Iowa from September 1998 through October 2000 using sweep nets. The proportion of $P$. stewartii-infested beetles at the end of the 1998 growing season ranged from 0.04 to 0.19 . In spring 1999 , the proportion of overwintering adult corn flea beetles infested with $P$. stewartii ranged from 0.10 to 0.11 and did not differ significantly from the previous fall based on $\chi^{2}$. During the 1999 corn-growing season, the proportion of infested corn flea beetles

ranged from 0.04 to 0.86 , with the highest proportions occurring in August. In fall 1999, the proportion of beetles infested with P. stewartii ranged from 0.20 to 0.77 . In spring 2000 , the proportion of overwintering adult corn flea beetles infested with $P$. stewartii ranged from 0.08 to 0.30 ; these proportions were significantly lower than the proportions observed in fall 1999 at Ames, Chariton, and Nashua. During the 2000 corngrowing season, the proportion of $P$. stewartii-infested corn flea beetles ranged from 0.08 to 0.53 , and the highest observed proportions again occurred in August. Corn flea beetle populations sampled in late fall 2000 had proportions of infested beetles ranging from 0.08 to 0.20 . This is the first study to quantify the temporal population dynamics of $P$. stewartii-infested $C$. pulicaria populations in hybrid corn and provides new quantitative information that should be useful in developing risk models to predict the seasonal and site-specific risks associated with Stewart's disease of corn.

Additional keywords: contingency tables, disease forecasting, risk assessment.

Stewart's disease of corn (Zea mays), caused by Pantoea stewartii $(15,25)$, is an economically important disease of sweet corn and seed corn $(3,18,19)$. Direct yield losses of 10 to $20 \%$ have been documented in sweet corn $(17,27)$. Due to phytosanitary regulations that limit export of seed corn originating from infested fields (14), there is a zero tolerance threshold for Stewart's disease in the seed corn industry. Before seed corn companies can export seed harvested from fields found to have Stewart's disease, they are required to perform costly grow-out tests or to employ enzyme-linked immunosorbent assays (ELISA) to verify that seed corn intended for export markets is free of $P$. stewartii (2). Therefore, this disease has tremendous economic implications in Iowa, considering that the prevalence of Stewart's disease in Iowa was $25 \%$ of seed production fields in 1998 and $58 \%$ in both 1999 and $2000(8,17)$.

For many years, plant-to-seed and seed-to-seedling transmission of this bacterium were considered to be epidemiologically important, thus prompting the phytosanitary regulations that are in place as a means to prevent the introduction of $P$. stewartii to other countries $(19,22)$. Recently, however, Khan et al. (12) showed that seed-to-seedling transmission did not occur in over 75,000 seed that were harvested from infected corn plants. Block et al. (2) also showed that the rate of plant-to-seed transmission was extremely low. Only $0.07 \%$ of corn seed produced from $P$. stewartii-inoculated corn plants became infected with $P$. stewartii,

Corresponding author: F. W. Nutter, Jr.; E-mail address: fwn@iastate.edu

Publication no. P-2002-1213-02R

(C) 2003 The American Phytopathological Society while naturally infected corn plants had plant-to-seedling transmission values of $0.003 \%$. Michener et al. (16) also recently reported that the risk of plant-to-seed transmission was low in resistant hybrids, ranging from 0.0007 to $0.024 \%$. Block et al. (2) further showed that seed-to-seedling infection occurred in only $0.14 \%$ of seedlings harvested from infected seed and that only $0.022 \%$ of seedlings became infected from seed arising from naturally infected plants. In spite of these low rates of transmission, strict quarantine sanctions remain in effect for Stewart's disease $(2,3)$.

$P$. stewartii is disseminated by the adult corn flea beetle (Chaetocnema pulicaria Melsheimer) $(6,20,23)$. Corn flea beetles acquire the bacterium while feeding on infected corn plants and then transmit the bacterium to healthy plants through feeding wounds. Depending on the stage of crop development when pathogen transmission occurs, two phases of Stewart's disease may develop (seedling wilt and late leaf blight) $(7,19)$. The seedling wilt phase occurs when $P$. stewartii-infested corn flea beetles feed on young corn plants and successfully transmit the bacterium (19). Following transmission, linear, water-soaked lesions develop on susceptible hybrids, followed by stunting and wilting $(5,19,22,25)$. When the seedling wilt phase is severe, seedlings may die. Symptoms of the late leaf blight phase typically originate from the sites of corn flea beetle-feeding wounds $(3,4,19)$. The bacterium multiplies within leaves and causes a yellowish, water-soaked lesion or streak that becomes necrotic. These streaks elongate and then coalesce along the leaf veins of corn leaves. When the leaf blight phase is severe on susceptible hybrids, entire leaves (and plants) can be blighted and killed.

There is little quantitative information concerning the dynamics of $P$. stewartii-infested corn flea beetle populations. By 
crushing and culturing the contents of adult corn flea beetles onto agar plates, Elliot and Poos (7) estimated that approximately 20 to $30 \%$ of the approximately 4,800 corn flea beetles they tested had the bacterium. Roberts (24) estimated that 10 to $20 \%$ of corn flea beetle populations that emerged from winter dormancy were infested with $P$. stewartii; however, testing during the midsummer months revealed that the percentage of infested beetles could be as high as $75 \%$ (24). The temporal dynamics of $P$. stewartii-infested corn flea beetles was not investigated in these studies. Heichel et al. (11) monitored temporal changes in the proportion of $P$. stewartii-infested corn flea beetles over 11 sampling dates within a single season. They observed a range of 40 to $70 \%$ of $P$. stewartii-infested corn flea beetles using agar media, but early spring and late fall sampling and testing was not performed.

An ELISA to test for the presence of $P$. stewartii in corn seed (13) could be modified and used to detect and quantify the presence of $P$. stewartii in corn flea beetle populations. Although previous studies have provided limited quantitative information concerning the proportion of corn flea beetles infested with $P$. stewartii, the proportions of $P$. stewartii-infested beetles at the end of one growing season (before overwintering) have not been compared with the proportion of $P$. stewartii-infested corn flea beetles present at the beginning of the ensuing corn growing season (after overwintering). This information would provide additional quantitative information concerning the primary source of initial inoculum and how inoculum levels $(P$. stewartii-infested corn flea beetles) fluctuate from the beginning of one growing season to the beginning of the next. The objective of this study was to quantify the temporal dynamics of corn flea beetle populations infested with $P$. stewartii by sampling and testing (by ELISA) individual corn flea beetles obtained from several locations in Iowa over time.

\section{MATERIALS AND METHODS}

Corn flea beetles were sampled from seven locations in Iowa using sweep net protocols that have been described previously (9). Ten replications of 10 sweeps per replication (6-m transects) were obtained each week from the grass borders adjacent to and surrounding corn fields beginning in early spring (prior to the time of corn planting) and continuing until corn seedlings reached the V5 growth stage (fifth vegetative leaf stage). Only grass borders adjacent to corn fields were sampled up until the V5 growth stage to avoid damaging young corn seedlings by sweep netting. After the V5 growth stage, sweep net samples were taken weekly within corn fields until corn was harvested. In 2000, separate sweep net samples also were taken from both the grass borders as well as from corn fields throughout the corn-growing season. After corn had senesced, sweep net samples were again obtained only from the grass borders (on a near-weekly basis) until corn flea beetles were no longer found in sweep net samples. Following each collection on each sampling date, the contents from sweep net samples were placed in $\mathrm{a}-17.8^{\circ} \mathrm{C}$ freezer for $24 \mathrm{~h}$ and corn flea beetles were then separated from other insects and debris. Approximately 90 corn flea beetles per location per sampling date were assayed by ELISA, however, less than 90 beetles were sometimes assayed when corn flea beetle populations were low. Corn flea beetle populations were sampled from seven Iowa State University Research Farms, all located in Iowa: the Been and Curtiss Farms in Ames (1999), the Bruner Research Farm in Ames (2000), the McNay Research Farm in Chariton (1999 and 2000), the Northeast Research Farm in Nashua (1999 and 2000), the Northern Research Farm in Kanawha (1999 and 2000), the Northwest Research Farm in Sutherland (1999 and 2000), and the Southeast Research Farm in Crawfordsville (1999 and 2000). Sweep net samples were collected from fall 1998 and continued throughout the entire 1999 and 2000 growing seasons and into late fall 2000. Individual corn flea beetles were tested for the presence of $P$. stewartii using a modified compound-direct, peroxidaselabeled ELISA protocol (Agdia Inc., Elkhart, IN). The modifications described below were done to facilitate detection of $P$. stewartii in individual corn flea beetles as opposed to detecting $P$. stewartii in corn seed samples (13).

A 96-well microtiter plate (Nunc-Immuno Plate, Roskilde, Denmark) was used for sample preparation. One hundred microliters of $1 \times$ PBST buffer ( $8.0 \mathrm{~g}$ of $\mathrm{NaCl}, 1.15 \mathrm{~g}$ of $\mathrm{Na}_{2} \mathrm{HPO}_{4}, 0.2 \mathrm{~g}$ of $\mathrm{KH}_{2} \mathrm{PO}_{4}, 0.2 \mathrm{~g}$ of $\mathrm{KCl}, 0.5 \mathrm{~g}$ of Tween 20 , and $1,000 \mathrm{ml}$ of $\mathrm{dH}_{2} \mathrm{O}, \mathrm{pH}$ 7.4) was placed into each well. A single corn flea beetle then was placed into each well, and each beetle was ground using a sterile, 5-mm-diameter glass rod. After grinding, an additional $175 \mu \mathrm{l}$ of $1 \times$ PBST was added to each well. From these wells, two $100-\mu \mathrm{l}$ aliquots were analyzed in precoated ELISA plates. Two positive and two negative controls obtained from leaf tissue were used in each test (Agdia Inc.). The remainder of the ELISA test was performed following the methods described by Agdia Inc. The absorbance of each well was recorded at $490 \mathrm{~nm}$ with a microplate reader $\left(\mathrm{EL}_{\mathrm{x}} 800\right.$ Universal; Bio-Tek Instruments, Inc., Winooski, VT). A sample (beetle) was considered positive if the absorbance value for both subsamples from a single corn flea beetle was $\geq 2 \times$ the mean absorbance of the negative control samples $(2,3)$.

Data analysis. Proportions of $P$. stewartii-infested corn flea beetles for each sampling date were determined based on the number of corn flea beetles testing positive for P. stewartii divided by the total number of corn flea beetles tested. A standard error for the proportion of $P$. stewartii-infested corn flea beetles for each sampling date and location was calculated using the following equation:

$$
\text { StdError }=\sqrt{\frac{p(1-p)}{n}}
$$

where $p$ is the proportion of positive samples, $l-p$ is the proportion of negative samples, and $n$ is the total number of corn flea beetles (samples) tested (26).

The proportion of $P$. stewartii-infested corn flea beetles found at the last sampling date of the season (i.e., when corn flea beetles were found in numbers sufficient to test) was compared with the proportion of $P$. stewartii-infested corn flea beetles found at the first sampling date of the next growing season (i.e., when adult corn flea beetles first were detected and sampled from the different locations in early spring). The respective proportions of $P$. stewartii-infested corn flea beetles sampled in the late fall versus the proportions found to be infested on the first sampling date the following spring (prior to corn seeding) were analyzed by $\chi^{2}$ for independence using PROC FREQ statements in SAS (SAS version 8; SAS Institute, Cary, NC). The hypothesis that the proportion of adult overwintering $P$. stewartii-infested corn flea beetles would remain static to the time that corn seedlings had emerged was tested for each location and year in which $>2$ sampling dates were obtained in the early spring using the PROC FREQ statement in SAS for $K \times 2$ contingency tables.

The proportion of $P$. stewartii-infested corn flea beetles per $6-\mathrm{m}$ sweep net transect (10 sweeps) was determined for each sampling date and location for which two full field seasons of corn flea beetle activity was obtained. To calculate this proportion, the number of corn flea beetles per $6 \mathrm{~m}$ was multiplied by the estimated proportion of $P$. stewartii-infested corn flea beetles for each specific sampling date and location. To estimate and model the temporal dynamics of $P$. stewartii-infested corn flea beetles for these data, we fit a cubic quadratic function (smooth.spline) using S-plus (S-plus 6.1 for Windows; Insightful Corp., Seattle, WA) This is a nonparametric smoothing function to model the proportion of $P$. stewartii-infested corn flea beetles over time $(4,10)$. 


\section{RESULTS}

Comparison of late fall and early spring infestations. The proportions of corn flea beetles infested with $P$. stewartii in spring 1999 were not significantly different from the proportions of $P$. stewartii-infested corn flea beetles in fall 1998 at Ames, Chariton, and Crawfordsville (Table 1). However, the proportions of $P$. stewartii-infested corn flea beetles were found to be significantly lower in spring 2000 compared with fall 1999 at Ames $(P<$ $0.0001)$, Chariton $(P<0.0001)$, and Nashua $(P=0.0365)$ (Table 1). In contrast, significant differences in the proportions of $P$. stewartii-infested corn flea beetles were not observed between fall 1999 and spring 2000 samples for three sampling locations (Crawfordsville, Kanawha, and Sutherland). Due to adverse weather conditions the previous winter, corn flea beetles were not found at Nashua in fall 1998, or at Kanawha and Sutherland in spring 1999 (Table 1) and, therefore, $\chi^{2}$ could not be performed for these location-years.

Temporal dynamics of $\boldsymbol{P}$. stewartii-infested adult (overwintering) corn flea beetles in the spring. The hypothesis that the proportion of $P$. stewartii-infested corn flea beetles would not fluctuate in the early spring (prior to sampling in corn fields) was rejected for corn flea beetles collected during the early spring from Chariton in $1999(P=0.003)$ and $2000(P=0.028)$ (Table 2$)$. This hypothesis was not rejected for any other location-years.

Beetle-free period. Periods when corn flea beetle populations could not be found (beetle-free periods) ranged from 14 to 32 days in 1999 at Ames (7 June to 9 July), Chariton (7 to 21 June), and Crawfordsville ( 7 to 21 June) (Table 3). In 2000, the beetle-free period ranged from 14 to 21 days among the six locations in Iowa (Table 3). During beetle-free periods, no ELISA testing could be performed and, therefore, no inoculum (in beetles) was present during this period.
Growing-season dynamics. In 1999, the number of corn flea beetles tested during the growing season from a specific location and for a specific sampling date ranged from 10 to 180 (Figs. 1 and 2). The proportions of $P$. stewartii-infested corn flea beetles observed during the growing season ranged from $0.043 \pm 0.043$ to $0.856 \pm 0.037$ (Table 4; Figs. 1 and 2). In general, the highest observed proportions of $P$. stewartii-infested corn flea beetles occurred near the end of August (day of year [DOY] 243) at each of the six locations.

In 2000, the number of corn flea beetles tested from a specific location and for a specific sampling date in 2000 ranged from 6 to 135. The proportions of corn flea beetles infested with $P$. stewartii in 2000 ranged from $0.078 \pm 0.028$ to $0.533 \pm 0.074$ (Table 4; Figs. 1 and 2). Again, the highest observed proportions of $P$. stewartii-infested corn flea beetles occurred near the end of August (DOY 244).

TABLE 3. Periods in 1999 and 2000 when corn flea beetles were not found, and therefore, no enzyme-linked immunosorbent assay tests were performed

\begin{tabular}{llr}
\hline & \multicolumn{2}{c}{ Beetle-free period $^{\mathrm{a}}$} \\
\cline { 2 - 3 } Location & \multicolumn{1}{c}{1999} & \multicolumn{1}{c}{2000} \\
\hline Ames & 7 June-9 July & 7-21 June \\
Chariton & 7-21 June & 7-21 June \\
Crawfordsville & 7-21 June & 7-21 June \\
Kanawha & NA & 12-26 June \\
Nashua & NA & 5-26 June \\
Sutherland & NA & 5-26 June
\end{tabular}

a Beetle-free period is defined as the period of time when overwintering adult corn flea beetles have laid their eggs and died and the first summer generation have not hatched or undergone larval development to become adult beetles. NA = data not available because corn flea beetle populations were very low in the early spring and first summer generation.

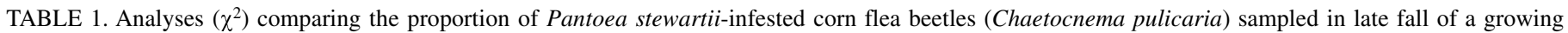
season with the first sampling date the following spring

\begin{tabular}{|c|c|c|c|c|c|c|c|c|c|}
\hline \multirow[b]{2}{*}{ Location } & \multirow[b]{2}{*}{ Comparison $^{\mathrm{a}}$} & \multicolumn{3}{|c|}{ Fall } & \multicolumn{3}{|c|}{ Spring } & \multirow[b]{2}{*}{$\chi^{2}$ value } & \multirow[b]{2}{*}{$P \geq \chi^{2 \mathrm{~b}}$} \\
\hline & & No. & Proportion & Standard error & No. & Proportion & Standard error & & \\
\hline \multirow[t]{2}{*}{ Ames } & F1998 vs. S1999 & 45 & 0.074 & 0.050 & 20 & 0.100 & 0.067 & 0.2167 & 0.6416 \\
\hline & F1999 vs. S2000 & 90 & 0.433 & 0.052 & 90 & 0.156 & 0.038 & 16.7137 & $<0.0001 *$ \\
\hline \multirow[t]{2}{*}{ Chariton } & F1998 vs. S1999 & 45 & 0.044 & 0.031 & 44 & 0.114 & 0.048 & 1.4698 & 0.2254 \\
\hline & F1999 vs. S2000 & 90 & 0.733 & 0.047 & 90 & 0.300 & 0.048 & 33.8376 & $<0.0001^{*}$ \\
\hline \multirow[t]{2}{*}{ Crawfordsville } & F1998 vs. S1999 & 45 & 0.156 & 0.054 & 45 & 0.111 & 0.047 & 0.3846 & 0.5351 \\
\hline & F1999 vs. S2000 & 135 & 0.200 & 0.034 & 135 & 0.170 & 0.032 & 0.3927 & 0.5309 \\
\hline Kanawha $^{c}$ & F1999 vs. S2000 & 22 & 0.227 & 0.089 & 25 & 0.080 & 0.054 & 2.0024 & 0.1571 \\
\hline Nashua $^{c}$ & F1999 vs. S2000 & 88 & 0.239 & 0.045 & 45 & 0.089 & 0.042 & 4.3742 & $0.0365 *$ \\
\hline Sutherland ${ }^{\mathrm{c}}$ & F1999 vs. S2000 & 112 & 0.241 & 0.040 & 22 & 0.136 & 0.073 & 1.1602 & 0.2814 \\
\hline
\end{tabular}

${ }^{a} \mathrm{~F}=$ fall sampling and $\mathrm{S}=$ spring sampling.

b Asterisk indicates $\chi^{2}$ values that are significant at the 0.05 level.

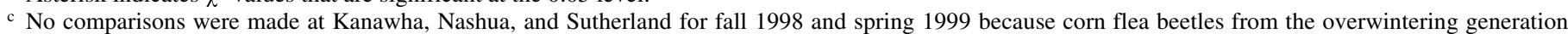
were not found in 1999.

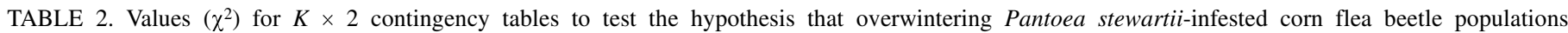
(Chaetocnema pulicaria) obtained from sweep-net sampling of grass plants remain static over time prior to the emergence of corn seedlings

\begin{tabular}{|c|c|c|c|c|c|}
\hline Location & Year $^{\mathrm{a}}$ & No. of sampling dates ${ }^{b}$ & $\chi^{2}$ value & $P \geq \chi^{2 \mathrm{c}}$ & Range of proportions \\
\hline Ames & 2000 & 7 & 9.45 & 0.150 & $0.15-0.36$ \\
\hline Chariton & 1999 & 3 & 11.75 & $0.003^{*}$ & $0.11-0.46$ \\
\hline Chariton & 2000 & 3 & 7.19 & $0.028 *$ & $0.07-0.30$ \\
\hline Crawfordsville & 1999 & 3 & 2.47 & 0.290 & $0.10-0.27$ \\
\hline Crawfordsville & 2000 & 4 & 2.12 & 0.548 & $0.17-0.24$ \\
\hline Kanawha & 2000 & 4 & 1.81 & 0.613 & $0.08-0.20$ \\
\hline Nashua & 2000 & 3 & 0.17 & 0.918 & $0.09-0.11$ \\
\hline Sutherland & 2000 & 3 & 1.06 & 0.588 & $0.07-0.14$ \\
\hline
\end{tabular}

a In 1999, only one sampling date was obtained at Ames, while no corn flea beetles were found at Kanawha, Nashua, and Sutherland.

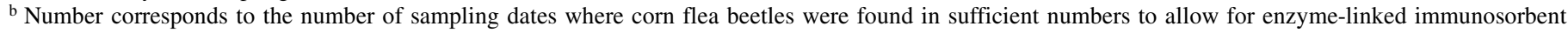
assay to be used to test beetles.

c Asterisk corresponds to significance at the 0.05 level. 
By fitting a cubic smoothing function to the proportional data obtained throughout the growing season, the estimated highest observed proportions of $P$. stewartii-infested corn flea beetles occurred approximately on DOY 250 at Ames, between DOY 235 to 240 at Chariton, and between DOY 225 to 235 at Crawfordsville in 1999 (Fig. 3). In 2000, the estimated highest observed proportions of $P$. stewartii-infested corn flea beetles occurred between DOY 195 and 200 at Ames, between DOY 180 and 190 at Chariton, and between DOY 205 and 215 at Crawfordsville (Fig. 4).

Estimated Pantoea stewartii-infested corn flea beetles per 6-m sweep-net transect. In 1999, the estimated number of overwintering adult $P$. stewartii-infested corn flea beetles ranged from 0.07 to 2.86 per 6-m sweep-net sampling transect (10 sweeps) (Tables 5 to 7). During the summer, the highest numbers of estimated $P$. stewartii-infested corn flea beetles per 6-m sampling transect occurred when corn flea beetle populations were highest (mid-July through the end of August) (Tables 5 to 7). The estimated number of $P$. stewartii-infested corn flea beetles in the overwintering generation in early 2000 was as high as 13.2 per 6-m sweep-net sampling transect (Tables 5 to 7). During the summer months in 2000, the highest estimated populations of $P$. stewartii-infested corn flea beetles occurred during July in corn fields, ranging from 0.06 to 6.90 per 6-m sampling transect. However, when looking at samples collected from the grass borders adjacent to corn fields, the estimated number of $P$. stewartiiinfested corn flea beetles per 6-m sweep-net sampling transect in the grass borders was as high as 23.2 (Kanawha on 25 October) at the end of the sampling season (late September into October) (Tables 5 to 10 ).

Population dynamics of $\boldsymbol{P}$. stewartii-infested corn flea beetle populations in grass borders following corn senescence in 2000. In late fall 2000 , the proportions of $P$. stewartii-infested corn flea beetles in grass borders ranged from $0.083 \pm 0.056$ (Chariton) to $0.200 \pm 0.042$ (Nashua). The proportion of $P$. stewartii-infested corn flea beetles collected from other locations $(n=90)$ at the end of the 2000 growing season was $0.189 \pm 0.041$ at Ames, $0.089 \pm 0.030$ at Crawfordsville, $0.178 \pm 0.040$ at Kanawha, and $0.133 \pm 0.036$ at Sutherland.

\section{DISCUSSION}

There are three critical periods during a corn growing season with respect to $P$. stewartii inoculum levels in corn flea beetles. The first critical period occurs early in the spring, prior to the time
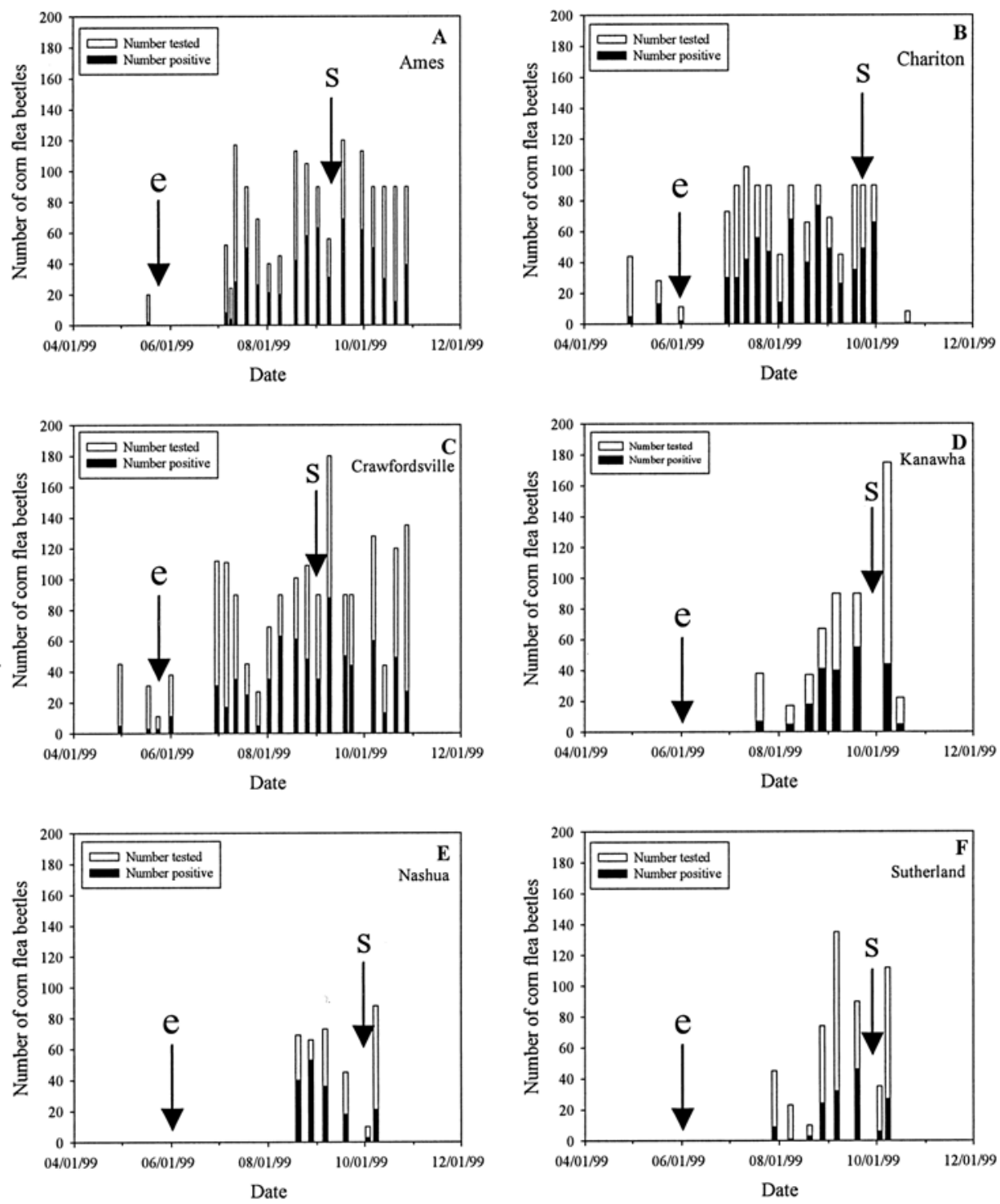

Fig. 1. Total number of corn flea beetles (Chaetocnema pulicaria) tested and the number of corn flea beetles testing positive for Pantoea stewartii at A, Ames, B, Chariton, C, Crawfordsville, D, Kanawha, E, Nashua, and F, Sutherland, IA in 1999. The "e" indicates the date of corn emergence and the "s" indicates the date of corn senescence. 
that corn is planted and corn seedlings emerge. During this period, the proportions of $P$. stewartii-infested corn flea beetles contribute to the severity of the seedling wilt phase of Stewart's disease. The second critical period begins after the beetle-free period that occurs in June. The end of the beetle-free period coincides with the emergence of the first summer corn flea beetle generation that begins to emerge in mid- to late June and continues to emerge into July (9). In Iowa, this would be just prior to the time that seed corn inspections are performed, which is a critical period for the late leaf blight phase of Stewart's disease. This is the period that affects the severity of the late leaf blight phase of Stewart's disease. Finally, the third critical period occurs during the second summer corn flea beetle generation that begins to emerge in August and continues until adult corn flea beetles can no longer be found in corn (8). The importance of this third critical period is that it is directly related to the amount of initial inoculum that will be available at the beginning of the next growing season. When coupled with models that predict the survival potential of overwintering corn flea beetle populations, quantitative information concerning inoculum levels present at the end of one growing season can help to improve preplant predictions for the ensuing season $(17,27)$.
Estimating the number of $P$. stewartii-infested corn flea beetles per 6-m sweep-net transects provides a measure of risk of Stewart's disease during July because the risk of Stewart's disease is likely to be a function of the size of the corn flea beetle population multiplied by the proportion of that population that is infested with $P$. stewartii. Therefore, reducing the risk of Stewart's disease through improved management of corn flea beetle populations is very important during this period. This suggests that an insecticide spray program may be required to protect susceptible corn inbreds and hybrid corn during this period.

The period in both 1999 and 2000 when we did not collect any corn flea beetles is also important in developing management recommendations. Without corn flea beetles to acquire and transmit inoculum from plant to plant during this period, the application of foliar insecticides is not warranted and would be economically and environmentally costly. Dill (6) indicated that $P$. stewartii is not passed from the adult female to eggs; therefore, we might expect that the proportions of $P$. stewartii-infested corn flea beetle inoculum levels resets to zero between each generation. We found that the proportions of $P$. stewartii-infested corn flea beetles between the first summer and second summer generations did not reset to zero. This is because these two generations
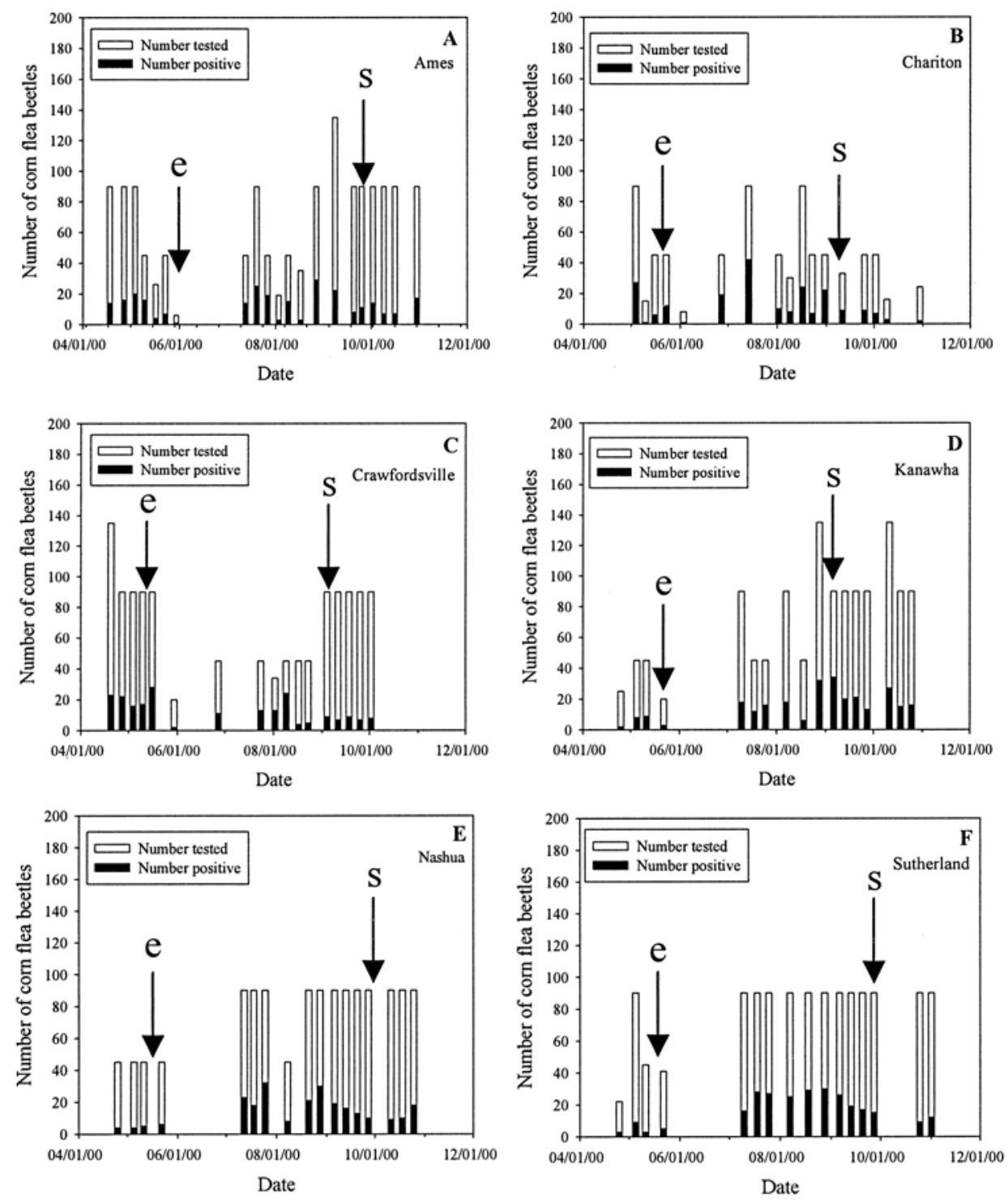

Fig. 2. Total number of corn flea beetles (Chaetocnema pulicaria) tested and the number of corn flea beetles testing positive for Pantoea stewartii at A, Ames, B, Chariton, C, Crawfordsville, D, Kanawha, E, Nashua, and F, Sutherland, IA in 2000. The "e" indicates the date of corn emergence and the "s" indicates the date of corn senescence. 
somewhat overlap between the end of July and early August (9) and the fact that corn flea beetles apparently can acquire the bacterium very quickly, as evidenced by the proportions of $P$. stewartii-infested corn flea beetles sampled and tested when the first summer corn flea beetle generation were just emerging in late June.

Monitoring $P$. stewartii-infested corn flea beetle inoculum levels from late August or early September (harvest) through the end of the fall season (DOY 212 to 304) is important for determining the potential risk for Stewart's disease the following spring. This is because the proportion of adult corn flea beetles that test positive for $P$. stewartii late in the fall likely will serve as the most important source of initial inoculum the following spring, if they survive the winter $(6,17,27)$. Although we observed significant reductions in the proportions of $P$. stewartii-infested corn flea beetles at three locations in Iowa for beetles collected

TABLE 4. Proportions of corn flea beetles testing positive for Pantoea stewartii by enzyme-linked immunosorbent assay (ELISA) during the 1999 and 2000 growing seasons at seven locations in Iowa ${ }^{\mathrm{a}}$

\begin{tabular}{lccc}
\hline Location & Year & Minimum & Maximum \\
\hline Ames (Been and Curtiss) & 1999 & $0.154 \pm 0.050$ & $0.700 \pm 0.048$ \\
Ames (Bruner) & 2000 & $0.078 \pm 0.028$ & $0.422 \pm 0.074$ \\
Chariton & 1999 & $0.311 \pm 0.069$ & $0.856 \pm 0.037$ \\
& 2000 & $0.156 \pm 0.054$ & $0.489 \pm 0.075$ \\
Crawfordsville & 1999 & $0.200 \pm 0.034$ & $0.700 \pm 0.048$ \\
& 2000 & $0.078 \pm 0.028$ & $0.533 \pm 0.074$ \\
Kanawha & 1999 & $0.184 \pm 0.063$ & $0.612 \pm 0.059$ \\
Nashua & 2000 & $0.133 \pm 0.051$ & $0.378 \pm 0.051$ \\
& 1999 & $0.239 \pm 0.049$ & $0.803 \pm 0.049$ \\
Sutherland & 2000 & $0.100 \pm 0.032$ & $0.356 \pm 0.050$ \\
& 1999 & $0.043 \pm 0.043$ & $0.511 \pm 0.053$ \\
- & 2000 & $0.100 \pm 0.032$ & $0.333 \pm 0.050$ \\
\hline
\end{tabular}

a Minimum or maximum observed proportion of $P$. stewartii-infested corn flea beetles testing positive using ELISA during the corn growing season; mean \pm standard error. late in fall 1999 compared with the surviving overwintering adult beetles first collected in spring 2000, this reduction in initial inoculum in 2000 was offset by the fact that the overall (total) corn flea beetle populations were significantly higher in spring 2000 compared with all other sampling times during the study period. As a result, the estimated populations of $P$. stewartiiinfested corn flea beetles per 6-m sweep-transect were as high as 13 in spring 2000 (9). Thus, the amount of inoculum available to initiate a Stewart's disease epidemic at a particular location is a function of the proportion of $P$. stewartii-infested corn flea beetles (y) times the size of the overwintering corn flea beetle population $(n)$.

The timing of the emergence of the overwintering generation in relation to corn emergence also is important. Information regarding the timing of the emergence of the overwintering corn flea beetle generation and the proportion of that population infested with $P$. stewartii has important management implications with regard to the time of planting because avoiding the peak emergence periods of overwintering populations of corn flea beetles already infested with the bacterium may greatly decrease the potential risk of Stewart's disease. Infested corn flea beetles were found 2 weeks earlier in 2000 than in 1999; thus, a larger amount of initial inoculum was available at the time corn seedlings were emerging, which greatly increased the risk for the seedling wilt phase of Stewart's disease in Iowa in 2000. Thus, planting after peak inoculum levels in the spring may have the potential to decrease disease risk.

The significant increase in the proportion of $P$. stewartii-infested corn flea beetle populations that occurred in early spring just prior to corn emergence at Chariton is extremely important for managing Stewart's disease. During that period, corn flea beetles were sampled only from the grass borders, because corn had not yet emerged (9). Our original hypothesis was that the proportion of $P$. stewartii-infested corn flea beetles emerging from winter dormancy would remain static until corn had emerged and noninfested corn flea beetles would then have the opportunity to
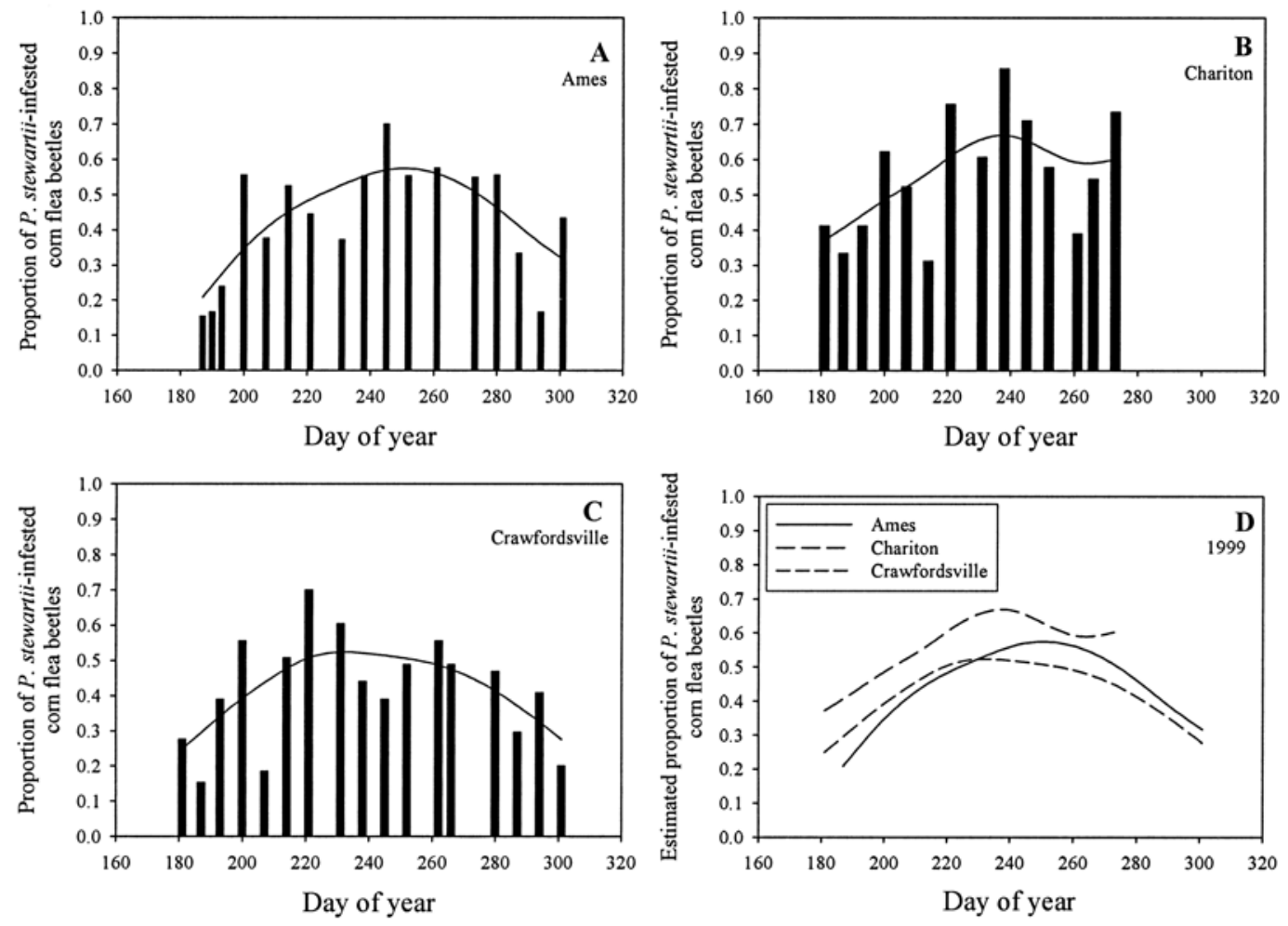

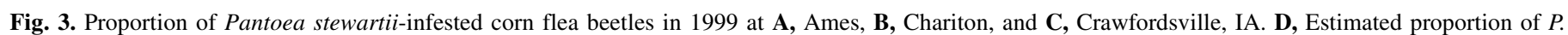
stewartii-infested corn flea beetles is shown by fitting a cubic smoothing function for the three locations. 
acquire the bacterium from infected seedlings. These newly infested beetles could then serve as potential vectors for pathogen transmission to healthy corn plants and the proportion of $P$. stewartii-infested corn flea beetles would increase. However, we observed at Chariton (both in 1999 and 2000) that the overwintering $P$. stewartii-infested corn flea beetle population doubled or tripled prior to the emergence of corn seedlings. This new information lends itself to three alternative hypotheses: (i) that there
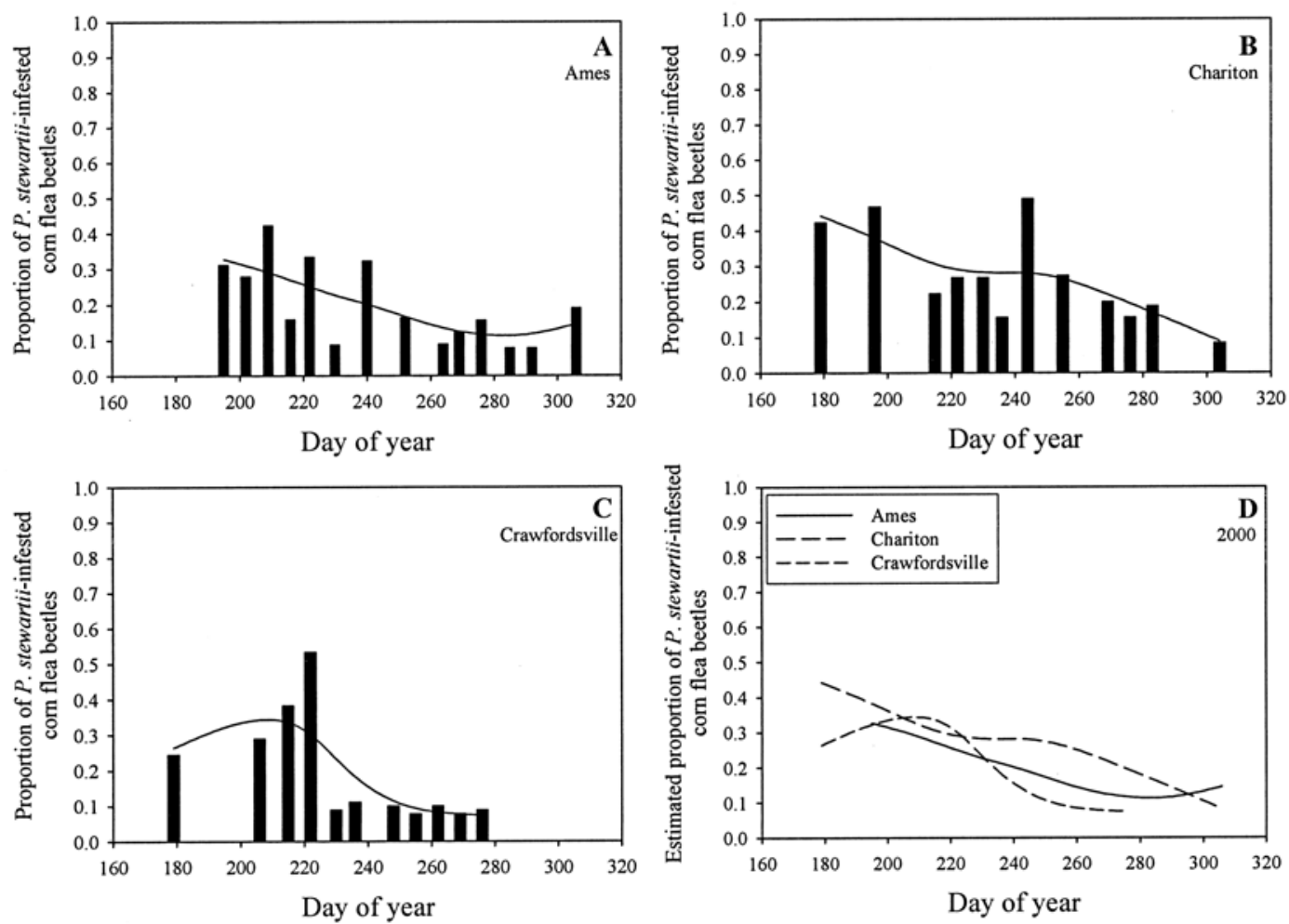

Fig. 4. Proportion of Pantoea stewartii-infested corn flea beetles in 2000 at A, Ames, B, Chariton, and C, Crawfordsville, IA. D, Estimated proportion of $P$. stewartii-infested corn flea beetles is shown by fitting a cubic smoothing function for the three locations.

TABLE 5. Estimated proportions of Pantoea stewartii-infested corn flea beetles (CFB) per 6-m sweep-net sampling transect (10 sweeps) at Ames, IA in 1999 to 2000

\begin{tabular}{|c|c|c|c|c|}
\hline Date & Source of CFB & CFB per transect & Proportion of $P$. stewartii-infested CFB & Estimated no. of infested CFB per transect \\
\hline 18 May 1999 & Grass & 2.1 & $0.100 \pm 0.067$ & $0.07-0.35$ \\
\hline 9 July 1999 & Corn & 2.5 & $0.167 \pm 0.076$ & $0.23-0.61$ \\
\hline 12 July 1999 & Corn & 6.1 & $0.239 \pm 0.039$ & $1.22-1.70$ \\
\hline 26 July 1999 & Corn & 4.9 & $0.377 \pm 0.058$ & $1.56-2.13$ \\
\hline 2 August 1999 & Corn & 3.0 & $0.525 \pm 0.079$ & $1.34-1.81$ \\
\hline 9 August 1999 & Corn & 1.9 & $0.444 \pm 0.074$ & $0.70-0.98$ \\
\hline 19 August 1999 & Corn & 13.1 & $0.372 \pm 0.045$ & $4.28-5.46$ \\
\hline 9 September 1999 & Corn & 2.1 & $0.554 \pm 0.066$ & $1.02-1.30$ \\
\hline 18 April 2000 & Grass & 44.9 & $0.156 \pm 0.038$ & $5.30-8.71$ \\
\hline 27 April 2000 & Grass & 30.0 & $0.178 \pm 0.040$ & $4.14-6.54$ \\
\hline 4 May 2000 & Grass & 11.1 & $0.222 \pm 0.044$ & $1.98-2.95$ \\
\hline 10 May 2000 & Grass & 3.4 & $0.356 \pm 0.071$ & $0.97-1.45$ \\
\hline 17 May 2000 & Grass & 1.8 & $0.154 \pm 0.071$ & $0.15-0.41$ \\
\hline 23 May 2000 & Grass & 3.9 & $0.156 \pm 0.054$ & $0.40-0.82$ \\
\hline 9 August 2000 & Corn & 0.6 & $0.333 \pm 0.070$ & $0.16-0.24$ \\
\hline 27 August 2000 & Corn & 2.0 & $0.322 \pm 0.049$ & $0.55-0.74$ \\
\hline 8 September 2000 & Corn & 0.7 & $0.162 \pm 0.032$ & $0.09-0.14$ \\
\hline 20 September 2000 & Grass & 51.9 & $0.089 \pm 0.030$ & $3.06-6.18$ \\
\hline 25 September 2000 & Grass & 76.7 & $0.122 \pm 0.035$ & $6.67-12.04$ \\
\hline 2 October 2000 & Grass & 15.6 & $0.156 \pm 0.038$ & $1.84-3.03$ \\
\hline 9 October 2000 & Grass & 23.1 & $0.189 \pm 0.041$ & $3.42-5.31$ \\
\hline
\end{tabular}




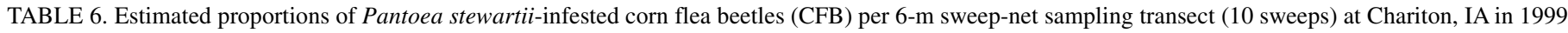
to 2000

\begin{tabular}{|c|c|c|c|c|}
\hline Date $^{\mathrm{a}}$ & Source of CFB & CFB per transect & Proportion of $P$. stewartii-infested CFB & Estimated no. of infested CFB per transect \\
\hline 30 April 1999 & Grass & 4.5 & $0.114 \pm 0.048$ & $0.30-0.73$ \\
\hline 18 May 1999 & Grass & 2.8 & $0.464 \pm 0.094$ & $1.04-1.56$ \\
\hline 1 June $1999 *$ & Grass & 1.0 & $0.182 \pm 0.116$ & $0.07-0.30$ \\
\hline 30 June 1999 & Corn & 2.3 & $0.411 \pm 0.058$ & $0.81-1.08$ \\
\hline 6 July 1999 & Corn & 2.1 & $0.333 \pm 0.050$ & $0.59-0.80$ \\
\hline 12 July 1999 & Corn & 6.4 & $0.412 \pm 0.049$ & $2.32-2.95$ \\
\hline 19 July 1999 & Corn & 16.7 & $0.622 \pm 0.051$ & $9.54-11.24$ \\
\hline 26 July 1999 & Corn & 10.1 & $0.522 \pm 0.053$ & $4.74-5.81$ \\
\hline 2 August 1999 & Corn & 2.8 & $0.311 \pm 0.069$ & $0.68-1.06$ \\
\hline 8 August 1999 & Corn & 6.8 & $0.756 \pm 0.045$ & $4.83-5.45$ \\
\hline 19 August 1999 & Corn & 5.9 & $0.606 \pm 0.060$ & $3.22-3.93$ \\
\hline 26 August 1999 & Corn & 9.6 & $0.856 \pm 0.037$ & $7.86-8.57$ \\
\hline 2 September 1999 & Corn & 7.5 & $0.710 \pm 0.055$ & $4.91-5.74$ \\
\hline 9 September 1999 & Corn & 1.0 & $0.578 \pm 0.074$ & $0.50-0.65$ \\
\hline 18 September 1999 & Corn & 0.4 & $0.389 \pm 0.051$ & $0.14-0.18$ \\
\hline 4 May 2000 & Grass & 10.9 & $0.300 \pm 0.048$ & $2.75-3.79$ \\
\hline 10 May 2000 & Grass & 0.7 & $0.067 \pm 0.064$ & $0.00-0.09$ \\
\hline 16 May $2000^{*}$ & Grass & 1.6 & $0.133 \pm 0.051$ & $0.13-0.29$ \\
\hline 23 May 2000 & Grass & 0.6 & $0.267 \pm 0.066$ & $0.12-0.20$ \\
\hline 3 June 2000 & Grass & 0.1 & $0.125 \pm 0.117$ & $0.00-0.02$ \\
\hline 27 June 2000 & Corn & 6.1 & $0.422 \pm 0.074$ & $2.12-3.03$ \\
\hline 14 July 2000 & Corn & 13.3 & $0.467 \pm 0.052$ & $5.52-6.90$ \\
\hline 2 August 2000 & Corn & 2.4 & $0.222 \pm 0.062$ & $0.38-0.68$ \\
\hline 9 August 2000 & Corn & 1.5 & $0.267 \pm 0.081$ & $0.28-0.52$ \\
\hline 17 August 2000 & Corn & 3.5 & $0.267 \pm 0.047$ & $0.77-1.10$ \\
\hline 23 August 2000 & Corn & 1.6 & $0.156 \pm 0.054$ & $0.16-0.34$ \\
\hline 31 August 2000 & Corn & 0.2 & $0.489 \pm 0.075$ & $0.08-0.11$ \\
\hline 11 September 2000 & Grass & 1.6 & $0.273 \pm 0.078$ & $0.31-0.56$ \\
\hline 25 September 2000 & Grass & 5.6 & $0.200 \pm 0.060$ & $0.78-1.46$ \\
\hline 2 October 2000 & Grass & 4.6 & $0.156 \pm 0.054$ & $0.47-0.97$ \\
\hline 9 October 2000 & Grass & 0.9 & $0.188 \pm 0.098$ & $0.08-0.26$ \\
\hline 30 October 2000 & Grass & 0.9 & $0.083 \pm 0.056$ & $0.02-0.13$ \\
\hline
\end{tabular}

a Asterisk indicates the time of corn emergence.

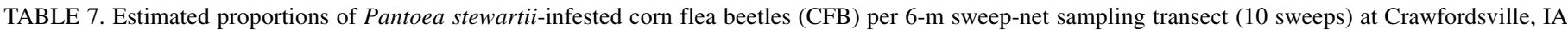
in 1999 to 2000

\begin{tabular}{|c|c|c|c|c|}
\hline Date $^{\mathrm{a}}$ & Source of CFB & CFB per transect & Proportion of $P$. stewartii-infested CFB & Estimated no. of infested CFB per transect \\
\hline 30 April 1999 & Grass & 18.1 & $0.111 \pm 0.047$ & $1.16-2.86$ \\
\hline 18 May 1999 & Grass & 3.1 & $0.097 \pm 0.053$ & $0.14-0.47$ \\
\hline 24 May $1999 *$ & Grass & 1.1 & $0.273 \pm 0.134$ & $0.15-0.45$ \\
\hline 1 June 1999 & Grass & 3.9 & $0.290 \pm 0.074$ & $0.84-1.42$ \\
\hline 30 June 1999 & Corn & 1.9 & $0.277 \pm 0.042$ & $0.45-0.61$ \\
\hline 6 July 1999 & Corn & 6.3 & $0.153 \pm 0.034$ & $0.75-1.18$ \\
\hline 12 July 1999 & Corn & 8.5 & $0.389 \pm 0.051$ & $2.87-3.74$ \\
\hline 2 August 1999 & Corn & 6.1 & $0.507 \pm 0.060$ & $2.73-3.46$ \\
\hline 9 August 1999 & Corn & 12.0 & $0.700 \pm 0.048$ & $7.82-8.98$ \\
\hline 19 August 1999 & Corn & 14.2 & $0.604 \pm 0.049$ & $7.88-9.27$ \\
\hline 26 August 1999 & Corn & 27.8 & $0.440 \pm 0.048$ & $10.90-13.57$ \\
\hline 2 September 1999 & Corn & 19.3 & $0.389 \pm 0.051$ & $6.52-8.49$ \\
\hline 9 September 1999 & Corn & 4.2 & $0.489 \pm 0.053$ & $1.83-2.28$ \\
\hline 19 September 1999 & Corn & 1.3 & $0.556 \pm 0.052$ & $0.66-0.79$ \\
\hline 20 April 2000 & Grass & 10.3 & $0.170 \pm 0.032$ & $1.42-2.08$ \\
\hline 27 April 2000 & Grass & 12.3 & $0.244 \pm 0.045$ & $2.45-3.55$ \\
\hline 4 May 2000 & Grass & 35.2 & $0.178 \pm 0.040$ & $4.86-7.67$ \\
\hline 10 May $2000 *$ & Grass & 57.3 & $0.189 \pm 0.041$ & $8.48-13.18$ \\
\hline 16 May 2000 & Grass & 8.8 & $0.311 \pm 0.049$ & $2.31-3.17$ \\
\hline 30 May 2000 & Grass & 1.5 & $0.100 \pm 0.067$ & $0.05-0.25$ \\
\hline 27 May 2000 & Corn & 0.9 & $0.244 \pm 0.064$ & $0.16-0.28$ \\
\hline 24 July 2000 & Corn & 5.7 & $0.289 \pm 0.068$ & $1.26-2.03$ \\
\hline 2 August 2000 & Corn & 2.6 & $0.382 \pm 0.083$ & $0.78-1.21$ \\
\hline 9 August 2000 & Corn & 0.6 & $0.533 \pm 0.074$ & $0.28-0.36$ \\
\hline 17 August 2000 & Corn & 2.1 & $0.089 \pm 0.042$ & $0.10-0.28$ \\
\hline 23 August 2000 & Corn & 2.1 & $0.111 \pm 0.047$ & $0.13-0.33$ \\
\hline 4 September 2000 & Corn & 1.9 & $0.100 \pm 0.032$ & $0.13-0.25$ \\
\hline 11 September 2000 & Corn & 0.1 & $0.078 \pm 0.028$ & $0.01-0.01$ \\
\hline 18 September 2000 & Corn & 0.1 & $0.100 \pm 0.032$ & $0.01-0.01$ \\
\hline 25 September 2000 & Grass & 34.5 & $0.078 \pm 0.028$ & $1.73-3.66$ \\
\hline 2 October 2000 & Grass & 23.4 & $0.089 \pm 0.030$ & $1.38-2.78$ \\
\hline
\end{tabular}

a Asterisk indicates the time of corn emergence. 
are alternative grass hosts from which the bacterium can be acquired and then transmitted to corn, (ii) that corn flea beetles are able to transmit the bacterium to one another prior to corn emergence, or (iii) that both (i) and (ii) are occurring. It also may be possible that the bacterium multiplies in the corn flea beetles after acquisition, increasing from nondetectable (by ELISA) levels early in the spring to detectable levels later in the spring. In preliminary research during 2000, we sampled grass plants surrounding corn fields and found that approximately $7 \%$ of those samples tested positive for Stewart's disease using ELISA (unpublished data). Further work is needed in this area to determine the epidemiological importance of alternative weed hosts in this pathosystem, as well as the possibility of beetle-to-beetle transmission.

We have shown that the proportion of $P$. stewartii-infested corn flea beetles fluctuates greatly throughout a year. The ability to determine the temporal relationships regarding the size of the insect vector population, the proportion of $P$. stewartii-infested corn flea beetle populations, and the development of the corn crop should further our understanding of the Stewart's disease pathosystem. Temporal patterns observed in our study concerning the population dynamics of the proportions of $P$. stewartii-infested corn flea beetles appear to be similar to those observed for malaria epidemics (1). The mathematical models that have been developed to describe malaria epidemics could be applied to the Stewart's disease pathosystem to develop risk assessment models addressing the three critical periods in a given year (early spring, early summer, late season) (1); however, quantitative information concerning pathogen acquisition and transmission periods in the corn flea beetle- $P$. stewartii pathosystem currently are lacking. Further research is needed to address the components of those models in controlled studies. With continued research, an effective integrated disease management program could be developed to more effectively reduce the risk of Stewart's disease in both seed and sweet corn.

\section{ACKNOWLEDGMENTS}

Journal Paper J-19442 of the Iowa Agriculture and Home Economics Experiment Station, Ames, Project No. 3394, and supported by Hatch Act and State of Iowa funds. We thank Pioneer Hi-Bred, Syngenta, and DeKalb for support of this research project; the Iowa State University Center For Advanced Technology Development for providing financial support; M. Gleason, G. Munkvold, J. Obrycki, and S. Wegulo for critical review of this manuscript; and P. Dixon (Department of Statistics) for statistical advice concerning data analysis.

\section{LITERATURE CITED}

1. Anderson, R. M., and May, R. M. 1995. Infectious Diseases of Humans. Oxford Science Publications, Oxford.

2. Block, C. C., Hill, J. H., and McGee, D. C. 1998. Seed transmission of Pantoea stewartii in field and sweet corn. Plant Dis. 82:775-780.

3. Block, C. C., Hill, J. H., and McGee, D. C. 1999. Relationship between late-season severity of Stewart's bacterial wilt and seed infection in maize. Plant Dis. 83:527-530.

4. Bowman, A. W., and Azzalini, A. 1997. Applied Smoothing Techniques for Data Analysis. Clarendon Press, Oxford.

5. Carlton, W. M., and Munkvold, G. P. 1995. Corn Stewart's Disease. Iowa State Univ. Ext. Bull. Pm-1627.

6. Dill, J. F. 1979. Biology and management of the corn flea beetle, Chaetocnema pulicaria Melshheimer, relative to the incidence of Stewart's disease in corn. Ph.D. thesis. Purdue University, West Lafayette, IN.

7. Elliot, C., and Poos, F. W. 1940. Seasonal development, insect vectors, and host range of bacterial wilt of sweet corn. J. Agric. Res. 60:645-686.

8. Esker, P. D., and Nutter, F. W., Jr. 2000. Monitoring the dynamics of corn flea beetles infested with Pantoea stewartii by ELISA. (Abstr.) Phytopathology 90(suppl.):S22.

9. Esker, P. D., Obrycki, J., and Nutter, F. W., Jr. 2002. The temporal distribution of Chaetoconema pulicaria (Coleoptera: Chrysomelidae) populations in Iowa. J. Econ. Entomol. 95:739-747.

10. Härdle, W. 1991. Smoothing Techniques. Springer-Verlag, New York.

11. Heichel, G. H., Sands, D. C., and Kring, J. B. 1977. Seasonal patterns and reductions by carbofuran of Stewart's bacterial wilt of sweet corn. Plant Dis. Rep. 61:149-153.

12. Khan, A., Ries, S. M., and Pataky, J. K. 1996. Transmission of Erwinia stewartii through seed or resistant and susceptible field and sweet corn. Plant Dis. 80:398-403.

13. Lamka, G. L., Hill, J. H., McGee, D. C., and Braun, E. J. 1991. Development of an immunosorbent assay for seedborne Erwinia stewartii in corn seeds. Phytopathology 81:839-846.

14. McGee, D. C. 1995. Epidemiological approach to disease management through seed technology. Annu. Rev. Phytopathol. 33:445-466.

15. Mergaert, J., Verdonck, L., and Kersters, K. 1993. Transfer of Erwinia ananas (synonym, Erwinia uredovora) and Erwinia stewartii to the genus Pantoea emend. as Pantoea ananas (Serrano 1928) comb. nov. and Pantoea stewartii (Smith 1898) comb. nov., respectively, and description of Pantoea stewartii subsp. indologenes subsp. nov. Int. J. Syst. Bacteriol. 43:162-173.

16. Michener, P. M., Pataky, J. K., and White, D. G. 2002. Transmission of Erwinia stewartii from plants to kernels and reactions of corn hybrids to Stewart's wilt. Plant Dis. 86:167-172.

17. Nutter, F. W., Wegulo, S. N., Rubsam, R. R., Taylor, S. E., and Harri, J. A. 1998. Use of geospatially referenced disease and weather data to improve site-specific forecasts for Stewart's disease of corn. (Abstr.) Phytopathology 88(suppl.):S68.

18. Pataky, J. K. 1985. Relationships among reactions of sweet corn hybrids to Goss' wilt, Stewart's bacterial wilt, and northern corn leaf blight. Plant Dis. 69:845-848.

19. Pepper, E. H. 1967. Stewart's Bacterial Wilt of Corn, 4th ed. Heffernan Press, Worchester, MA.

20. Poos, F. W. 1955. Studies of certain species of Chaetocnema. J. Econ. Entomol. 48:555-563.

21. Poos, F. W., and Elliot, C. 1936. Certain insect vectors of Aplanobacter stewartii. J. Agric. Res. 52:585-608.

22. Rand, F. V., and Cash, L. C. 1924. Further evidence of insect dissemination of bacterial wilt of corn. Science 59:67-69.

23. Rand, F. V., and Cash, L. C. 1933. Bacterial wilt of corn. U.S. Dep. Agric. Tech. Bull. 362:1-22.

24. Roberts, A. L. 1955. Bacterial wilt and Stewart's leaf blight of corn. U.S. Dep. Agric. Farm. Bull. 2092:13.

25. Smith, E. F. 1914. Bacteria in Relation to Plant Diseases. Carnegie Institute of Washington, Washington, D.C.

26. Steel, R. G. D., Torrie, J. H., and Dickey, D. A. 1997. Principles and Procedures of Statistics, a Biometrical Approach, 3rd ed. McGraw-Hill, New York.

27. Stevens, N. E. 1934. Stewart's disease in relation to winter temperatures. Plant Dis. Rep. 18:141-149.

28. Suparyono, and Pataky, J. K. 1989. Influence of host resistance and growth stage at the time of inoculation on Stewart's wilt and Goss's wilt development and sweet corn hybrid yield. Plant Dis. 73:339-345. 